\title{
Unpacking the influence of flight booking websites to e-loyalty: empirical evidence from South East Asian Millennials
}

\author{
Revelando a influência dos sites de reservas de voos para a lealdade eletrónica: evidência empírica dos Millennials \\ do Sudeste Asiático
}

\author{
Donny Susilo \\ Asia University, Department of Business Administration \\ No. 500 Liufeng Road, Wufeng District, Taichung City, Taiwan 41354 \\ Donnysusilo777@gmail.com
}

\begin{abstract}
This study aims to understand how Southeast Asian Millennials become loyal to a flight booking website, using the results of an online survey and a E-loyalty model, and structural equation modeling. The findings show that good utilitarian features of websites can significantly increase brand equity and positive online experience (flow) of website users while good hedonic features of websites can significantly increase positive online experience and trust of website users. Brand equity, positive online experience and trust have a direct and significant effect on e-loyalty. When the brand equity of a website, positive online experience and trust of website users are higher, the e-loyalty of millennial customers towards the website is higher. The effect of utilitarian features on trust and hedonic features on brand equity are found to be insignificant. Nevertheless, all the other hypotheses are accepted. This study has successfully expanded Bilgihan's E-loyalty model application to a different product (flight booking websites) and geographical location (Southeast Asia), proving its generalizability.
\end{abstract}

Keywords: Online booking websites, Millennials, flight, e-loyalty.

\section{Resumo}

Este estudo visa entender como os Millennials do sudeste asiático se fidelizam a um site de reservas de voos, usando os resultados de uma pesquisa online e um modelo de lealdade eletrónica e modelagem de equações estruturais. Os resultados mostram que boas características utilitárias do site podem aumentar significativamente o valor da marca e a experiência online dos utilizadores, enquanto as características hedónicas do site podem aumentar significativamente a experiência online e a confiança dos utilizadores. O valor da marca, a experiência online e a confiança têm um efeito direto e significativo na lealdade eletrónica. Quando o valor da marca, a experiência online e a confiança dos utilizadores são mais elevados, a lealdade eletrónica dos clientes Millennials é maior. $O$ efeito das características utilitárias na confiança e das características hedónicas no valor da marca é insignificante. No entanto, todas as outras hipóteses são aceites. Este estudo expandiu com sucesso a aplicação do modelo de lealdade online de Bilgihan para um produto diferente (sites de reserva de voos) e localização geográfica (sudeste da Ásia), comprovando a sua generalização.

Palavras-chave: Sites de reservas online, Millennials, voos, lealdade eletrónica.

\section{Introduction}

Life events shape people's behaviors, values and preferences in life thus making people from each generation different from one another in the way they think, purchase and become loyal to a product. Due to this, generational segmentation is important to marketers so that they can effectively and efficiently maximize the outcome of their marketing effort. Understanding how generation $Y$ (Millennials) thinks gives a company a competitive advantage as a company that understands it can sell products by applying a suitable strategy for Millennials. This makes millennial consumers loyal resulting in continuous profits for the company (Bilgihan, 2016).

Millennials use websites much faster than the previous generations. They do not only care about text when surfing the internet but they also put high interest in images, videos and social features. As the first generation knowing technology and Internet from an early age, they consume technology and Internet daily and think modern technology is invented for them. Marketers should understand and respond to these unique millennial feelings and needs by designing a website that can satisfy millennial consumers as they book a flight ticket online. When satisfaction leads to loyalty, marketers can gain advantage from repeat orders (Bilgihan, 2016).

In Asia, Millennial consumers spent over 340 billion dollars in 2015. Millennials are a large market representing $25 \%$ of total population in the region. Therefore, their shopping and

spending behavior should be major concern to businesses (Mandal \& Vong, 2016). However, the same authors said that as negative consequence of their online behavior, Millennials easily switch to others brand due to exposure to many brand ads and alternatives. This includes Southeast Asian Millennials. Therefore there is a urgent need for loyalty research about Millennials as they are less loyal to brands compared to the previous generations (Olga et al, 2018).

Google and MediaCT (2012) conducted research about millennial travellers. They discovered that about $80 \%$ of travellers planned their trip by collecting data from the Internet and that $60 \%$ of them love spending more time on the Internet to find the best product or service with the best price. They relied on the Internet as source of information for everything including information about flight tickets, hotels, recommended places to visit and regulations for travellers. The Internet makes the world borderless. Therefore having a website as a platform to search for information could be a vital factor for building customer loyalty. If airline companies and flight booking service providers can understand this, they will find a good strategy to get repeat orders. Understanding the determinants of customer loyalty is essential for retaining longterm customers. Loyal customers help the company sustain its growth by recommending the brand to their relatives and colleagues. In spite of , $25 \%$ of world population today being categorized as millennial, there is limited study on online 
booking websites and therefore it is urgent for stakeholders all over the world to examine how loyalty of millennial can be made and maintained in this situation (Bilgihan, 2016). In other words, there is a research gap to find a comprehensive model for the e-loyalty of Millennials toward flight booking websites.

Southeast Asian countries have had a positive outlook for gross domestic product in recent years as a result of the ASEAN Economic Community. The Asian Development Bank (ADB) projected economic growth or gross domestic product (GDP) in 10 Southeast Asian countries to be of $4.9 \%$ in 2019, with a slight increase to $5 \%$ in 2020. Increasing economic growth will lead to more spending in many sectors including travel. This research aims to examine the factors that affect Millennials' customer eloyalty to flight booking websites. This study is beneficial to governments, airlines companies and others flight booking service providers in determining and formulating website strategies in order to achieve customer loyalty.

\section{Theoretical background}

\subsection{Generational Theory}

Generational theory argues that generational cohorts share life experiences that cause them to develop similar attitudes and beliefs to other people their age. Many researchers and business people in all kinds of industries are interested in generational factors and its particular patterns (Leask, Fyall \& Barron, 2014). Despite the controversy surrounding the theory, shared life experiences and social context are believed to trigger each generational cohort to develop different beliefs, expectations and views regarding their lives, producing different behaviors. It also results in unique characteristics for each generation. Generational theory has been chosen as grand theory of this study.

\subsection{Electronic Customer Relationship Management}

According to Hamid, Mousavi \& Partovi (2019) e-CRM (Electronic Customer Relationship Management) is a technique to enhance and expand marketing capabilities by integrating technology and elements of marketing science. E-CRM pays attention to the aspects of three periods, namely pre-purchase, at-purchase, and post-purchase. Pre-purchase aspects include website presentation, access to information, information quality, loyalty programs, and search capabilities. Website presentation is an element that refers to the images and information displayed on the website. Access to information refers to the level of ease for a customer to obtain information about products, prices, and services. Information quality is an element that refers to the accuracy of the content and also the update frequency of the website. Loyalty programs are program elements such as rewards and awards for loyal customers. Search capabilities are elements that make it easy for customers to search information quickly from a website (Mang'unyi, Khabala \& Govender 2018).

The at-purchase aspects include payment methods, privacy and security, promotions and ordering process or speed. Payment methods are elements that make it easy for customers to make payments on the website. Privacy and security are website elements that protect customer information data from irresponsible parties. Dynamic pricing is an element of price that can be customized based on the amount ordered. Promotions are elements that offer other products during the payment process. Ordering process or speed is an element regarding the choice of shipping services based on cost and speed of delivery. The Post-purchase aspects include problem solving, order tracking, and after sales services. Problem solving is a company's ability to solve problems related to the purchase. Order tracking is when a website informs customers about the position of their order. After sales services refers to the company's response to complaints and input from customers after purchases (Mang'unyi, Khabala \& Govender 2018).

\subsection{Interrelationship between Website Features and Flow}

Bilgihan (2016) argued that in online purchasing activity, customers expect both utilitarian and hedonic features to help in searching for the best product with the cheapest price. Utilitarian features deal with the functional value of a website such as detailed product information, reviews from customers, ease of comparing prices, the clarity of website provider information, and the perceived ease of navigation. Hedonic features deal with emotional value of a website such as beautiful design, interactivity, music and convenience of use. By having those features, customers experience "flow" or a unified online customer experience when using the website. Flow is defined as the experience of total concentration that is a positive online experience (Mahnke et al., 2015). Flow or positive online experience has attracted a lot of attention from reviewers and website use researchers in the last decade. Mahnke et al (2015) further pointed out that more utilitarian and hedonic features of website will lead to a better experience that makes a website user totally concentrated on the website and not distracted by external factors. Today, the tourism sector has employed new functions such as virtual tours to make customers more confident as they make travel decisions (Willems, Brengman \& Van Kerrebroeck, 2019). Following the findings of relevant prior studies and a literature review, the author formulated the hypotheses below.

H1: Hedonic features of flight booking websites have a significant positive direct effect on positive online experience (flow)

H2: Utilitarian features of flight booking websites have a significant positive direct effect on positive online experience (flow)

\subsection{Interrelationship between Website Features and Brand Equity}

The experience, feeling and learning of a customer towards a particular website will affect its brand equity. Consumer-brand relationships are based on customers' utilitarian and hedonic motivation, meaning that customers see one brand as different from another brand based on the brand's utilitarian and hedonic value communicated through marketing campaigns (Martín-Consuegra et al., 2019). These authors further said that the main value of the Internet lies in its ability to simplify information search and transaction processes, which is why a website should have features to accommodate that search. In addition, designing a website is strategic choice to create positive attitudes toward the brand. Meanwhile, Foroudi et al (2019) argued that by successfully improving website applications and features, an institution's brand image can be enhanced. In order to achieve maximum results, co-creation behaviour between user and company via website usage should be encouraged. Fu, Kang \& Tasci (2017) mentioned that companies should pay attention to colour, design and music elements to build connection between brand and consumer's 
self-image. Following the findings of relevant prior studies and a literature review, the hypotheses below have been formulated.

H3: Hedonic features of flight booking websites have a significant positive direct effect on brand equity

H4: Utilitarian features of flight booking websites have a significant positive direct effect on brand equity

\subsection{Interrelationship between Flow and Brand Equity}

The use of interactive websites for reservations or transactions provides opportunities to create a positive online experience, effectively foster brand equity and strengthen consumer trust for long-term relationship building (Jamshidi et al, 2018). Furthermore, the authors noticed that the positive outcomes of flow include a belief in the product or brand, customer confidence, product awareness and similarly. Once consumers gain positive experience, they will memorize the brand of the website they used. Another study by Fu, Kang \& Tasci (2017) revealed that on-site flow experience can produce a positive attitude toward a brand. The positive attitude may be optimally produced from a deep feeling of involvement, motivation and enjoyable experiences of customers when they use the website. Following the findings of relevant prior studies and literature reviews, the hypothesis below was formulated.

H5: Positive online experience (flow) has a significant positive direct effect on brand equity

\subsection{Interrelationship between Flow and Trust}

The fear of an undesirable or risky e-commerce transaction can be eliminated when the user has a positive online experience. Therefore, flow is believed to be predictor of trust in an online environment because when website successfully produces flow, website users will feel more comfortable, safe and relaxed. Positive experiences can create positive consumer attitudes that will lead to a positive perception toward the website (Bilgihan, 2016). Jamshidi et al (2018) also said that trust could be nurtured through positive online experiences in the context of technology service. A website for flight ticket reservation is example of technology service. Trust is important, especially in online business activities because the consumers feel that non face-to-face transactions are riskier than face-toface transactions. Following the findings of relevant prior studies and literature reviews, the hypothesis below was formulated.

H6: Positive online experience (flow) has a significant positive direct effect on trust

\subsection{Interrelationship between Flow and E-Loyalty}

Rose et al (2012) revealed that a company must build up online customer experiences continuously over time to enhance the loyalty of their customers. Companies today compete to give the best experience to their customers since this can make customers feel emotionally attached to the company and its brand, leading to repeat orders and loyalty to the company. This finding is confirmed by Su et al (2016) who said that flow will exert a positive effect on user loyalty. Customers will be motivated to use the website again when they enjoy and concentrate on using the website. When users have positive online experiences, they will be immersed in the website, an effect that can even be stronger if the website is more interactive (Bilgihan, 2016). Following these findings, the hypothesis below was formulated.

H7: Positive online experience (flow) has a significant positive direct effect on loyalty

\subsection{Interrelationship between Brand Equity and E-Loyalty}

Brand is a vital factor for customers when choosing which website they will visit to make an online purchase. Great brand equity will be advantageous for a company in competing with other providers. Brand equity is positively associated with the intention to continue using a website, which is one of main indicators of loyal customer (Bilgihan, 2016). The massive development of Internet technology has pushed researchers to extend the concept of brand loyalty to e-loyalty, which refers to a concept of loyalty in an online environment. Companies should pay more attention to E-brand experience when they intend to build E-loyalty. Users will also become more loyal to a website when the brand awareness of the website is high. Therefore, brands should be managed professionally maximize profits from the repeat orders of loyal customers (Quan et al, 2020). Following the findings of prior relevant studies and literature reviews, the hypothesis below was formulated.

H8: Brand equity has a significant positive direct effect on loyalty

\subsection{Interrelationship between Trust and E-Loyalty}

Wang, Wang, \& Liu (2016) said that trust is significant element in electronic commerce and that it can stimulate customer loyalty. The absence of trust can stop customers from making online purchases, something that is especially true in tourism due to intangible environment and insecurity of electronic commerce (Ritchie, Chien, \& Sharifpour, 2017). Trust does not come from personal relationships in a virtual context as it does not allow face-to-face interaction between sellers and consumers. Consumers' confidence in a website provider has to be built with reliability, ethics and appropriate manners. Therefore website providers have to put some convincing elements in their website such as reviews, certificates of excellence, guarantees and clearly identify the company to send positive signals to consumers that their company is reliable and trustworthy. This can create consumer trust towards website providers (Bilgihan, 2016). Following the findings of relevant prior studies and literature reviews, the hypothesis below was formulated.

\section{H9: Trust has a significant positive direct effect on loyalty}

\subsection{Interrelationship between Website Features and Trust}

In the e-commerce industry, e-retailers must pay a lot of attention to security measures so that customers can trust the website to guarantee the confidentiality of their personal information. Website security is a utilitarian online features that can increase the perceived usefulness of a website to customers (Kamal et al, 2018). Both utilitarian and hedonic features are important determinants in developing online trust, so design features that can evoke online trust should get attention when companies are formulating strategy. Visual appeal and ease of use are the most impactful generators of online trust (Pengnate \& Sarathy 2017). Visually appealing websites can evoke emotional attachment in users of the website since they will believe that the website is professionally managed by a reliable corporation. Meanwhile, ease of use can 
prevent users from making mistakes when they use the website. Following the findings of prior relevant studies and literature reviews, the hypotheses below have been formulated.
H10: The hedonic features of flight booking websites have a significant positive direct effect on trust

H11: The utilitarian features of flight booking websites have a significant positive direct effect on trust

Figure 1 - Theoretical Model

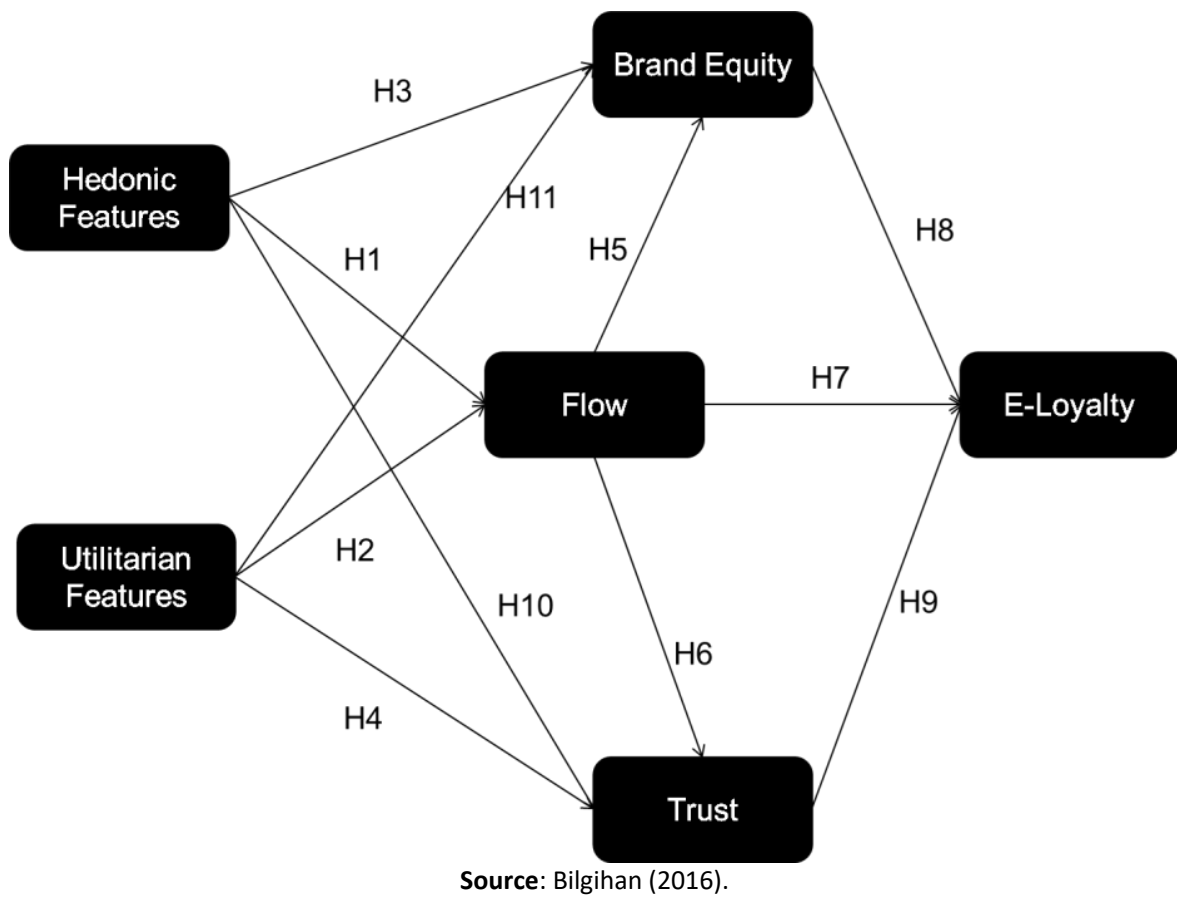

Based on customer loyalty construct above, 11 hypotheses were tested:

H1: The hedonic features of flight booking websites have a significant positive direct effect on positive online experience (flow)

H2: The utilitarian features of flight booking websites have a significant positive direct effect on positive online experience (flow)

H3: The hedonic features of flight booking websites have a significant positive direct effect on brand equity

H4: The utilitarian features of flight booking websites have a significant positive direct effect on brand equity

H5: Positive online experience (flow) has a significant positive direct effect on brand equity

H6: Positive online experience (flow) has a significant positive direct effect on trust

H7: Positive online experience (flow) has a significant positive direct effect on loyalty

H8: Brand equity has a significant positive direct effect on loyalty

H9: Trust has a significant positive direct effect on loyalty

H10: The hedonic features of flight booking websites have a significant positive direct effect on trust

H11: The utilitarian features of flight booking websites have a significant positive direct effect on trust

\section{Method}

The population of this research is generation $\mathrm{Y}$. Generation $\mathrm{Y}$ is a relatively new consumer segment of people born between 1980 and the mid-1990s. Because the internet existed when they were growing up, they are different from other generations in the way they think and perceive information. The popular term for this group of people is Millennials (Cavagnaro et al, 2018). Compared to the previous generations, Millennials have a unique character based on region and socio-economic conditions. One of their main characteristics is the advanced use of and familiarity with communication, media and digital technology. Because they live in an era of technological advancement, Millennials have creative, informative, passionate and productive traits. This generation involves technology in almost all aspects of their life. In the tourism sector, Millennials have a great potential to disrupt the industry with their high levels of digital skill, connectivity and altruistic behavior; they also expect for outstanding experiences when travelling (Veiga et al, 2017). Millennials love new things, they are more environmentally friendly and connected to peers compared to the previous generations but they are also more independent when travelling. They are the most active element in tourism industry (Kim \& Park, 2020). It is very beneficial for companies in the travel and tourism industry to understand Millennials because they travel more than any other previous generation (Ketter, 2020). Given the importance of millenials 
and their familiarity with technology, an online questionnaire is considered an appropriate method of data collection.

A quantitative causal approach was chosen to measure the effect significance of independent variables to dependent variable. Inferential statistic procedures were used to conduct this research, which meant that this research aimed to answer the research questions by collecting and analyzing data from a sample and then generalizing the results to a population. This study used a well-known customer loyalty construct that has been proven to be valid and reliable for hotel booking websites in the U.S. The questionnaire was modified to be suitable for flight booking websites, then it was translated into English and sent online to about 1.675 Millennials in the Southeast Asia countries of Indonesia, Malaysia, Singapore, Thailand and Vietnam. A 6-points Likert scale was used to measure the responses, evaluated accordingly: 1 = strongly disagree; 2 = disagree; 3 = somewhat disagree; 4 = somewhat agree; 5 = agree; 6 = strongly agree. Social media, online communities and email were employed as platforms to send the questionnaire. Some universities in Southeast Asia countries were also asked to collaborate and sent a link to the questionnaire via internal email as most students in university are categorized as Millennials. There were 408 responses received after several months. After removing incomplete responses and missing data, then 400 observations were recorded.

Table 1 - Constructs and measurement items

\begin{tabular}{|c|c|c|}
\hline Construct & Question items & Origin \\
\hline \multirow{4}{*}{$\begin{array}{l}\text { Positive } \\
\text { Online } \\
\text { Experience } \\
\text { (Flow) }\end{array}$} & POE_1: I experienced flow the last time that I booked my flight ticket on this website. & \multirow{4}{*}{$\begin{array}{l}\text { (Huang, 2005), } \\
\text { (Bilgihan, 2016) }\end{array}$} \\
\hline & POE_2: In general, I experience flow when I booked my flight ticket on this website. & \\
\hline & $\begin{array}{l}\text { POE_3: Most of the time when I booked my flight ticket on this website, I feel that I am } \\
\text { experiencing flow. }\end{array}$ & \\
\hline & POE_4: The last time that I booked my flight ticket on this website, I was fully engaged. & \\
\hline \multirow{5}{*}{$\begin{array}{l}\text { Hedonic } \\
\text { Features }\end{array}$} & HF_1: Weary-Entertaining & \multirow{5}{*}{ (Huang, 2003) } \\
\hline & HF_2: Disagreeable - Agreeable & \\
\hline & HF_3: Dull - Exciting & \\
\hline & HF_4: Not Delightful - Delightful & \\
\hline & HF_5: Not Thrilling - Thrilling & \\
\hline \multirow{4}{*}{$\begin{array}{l}\text { Utilitarian } \\
\text { Features }\end{array}$} & UF_1: Chaotic-Ordered & \multirow{4}{*}{ (Huang, 2003) } \\
\hline & UF_2: Unreliable - Reliable & \\
\hline & UF_3: Wrong - Correct & \\
\hline & UF_4: Not Functional - Functional & \\
\hline \multirow{4}{*}{ Trust } & T_1: I trust this flight booking website keeps my best interests in mind & \multirow{4}{*}{ (Morgan \& Hunt, 1994) } \\
\hline & T_2: This flight booking website will always be honest with me & \\
\hline & T_3: I believe in the information that this flight booking website provides & \\
\hline & T_4: This flight booking website is genuinely concerned about its customers & \\
\hline \multirow{4}{*}{$\begin{array}{l}\text { Brand } \\
\text { Equity }\end{array}$} & $\begin{array}{l}\text { BE_1: It makes sense to book my airfare ticket from this website instead of any other } \\
\text { websites, even if they are the same. }\end{array}$ & \multirow{4}{*}{$\begin{array}{l}\text { (Yoo, Donthu, \& Lee, } \\
\text { 2000) }\end{array}$} \\
\hline & $\begin{array}{l}\text { BE_2: Even if another flight booking website has same features as this website, I would } \\
\text { prefer to book through this website. }\end{array}$ & \\
\hline & $\begin{array}{l}\text { BE_3: If there is another brand as good as this website, I prefer to book my airfare ticket } \\
\text { through this website. }\end{array}$ & \\
\hline & $\begin{array}{l}\text { BE_4: If another flight booking website is not different from this website in any way, it } \\
\text { seems smarter to book through this website }\end{array}$ & \\
\hline \multirow{2}{*}{ e-Loyalty } & EL_1: As long as the present service continues, I doubt that I would switch websites. & \multirow{2}{*}{$\begin{array}{l}\text { (Chang \& Chen, 2009; } \\
\text { Lin \& Wang, 2006) }\end{array}$} \\
\hline & EL_2: To me this site is the best flight booking website to do business with. & \\
\hline
\end{tabular}

Source: Author (2020).

The collected data was tested with Explanatory Factor Analysis (EFA) in order to reduce the items of measurement by identifying the possible underlying variables (Miller, 2017). Confirmatory Factor Analysis (CFA) was then employed to verify measured variables to determinate if they represent the construct well or not (Hair et al, 2010). The preceding step was done to test the data's validity and reliability before the path analysis was conducted. SPSS 22 and AMOS 22 software were used to help with all of the processes.

\section{Results}

Data cleaning is the most critical first step in research analysis. Therefore the analysis began with a case processing analysis to see if there were any missing values in the collected data. Table 2 below presents the case processing summary. 
Table 2 - Case Processing Summary

\begin{tabular}{|l|c|c|c|c|c|c|}
\hline \multirow{2}{*}{} & \multicolumn{3}{|c|}{ Cases } \\
\cline { 2 - 6 } & \multicolumn{2}{|c|}{ Valid } & \multicolumn{3}{c|}{ Missing } & \multicolumn{2}{c|}{ Total } \\
\cline { 2 - 6 } & $\mathbf{N}$ & Percent & $\mathbf{N}$ & Percent & N & Percent \\
\hline Positive Online Experience & 400 & $100.0 \%$ & 0 & $0.0 \%$ & 400 & $100.0 \%$ \\
\hline Utilitarian Features & 400 & $100.0 \%$ & 0 & $0.0 \%$ & 400 & $100.0 \%$ \\
\hline Brand Equity & 400 & $100.0 \%$ & 0 & $0.0 \%$ & 400 & $100.0 \%$ \\
\hline E-Loyalty & 400 & $100.0 \%$ & 0 & $0.0 \%$ & 400 & $100.0 \%$ \\
\hline Hedonic Features & 400 & $100.0 \%$ & 0 & $0.0 \%$ & 400 & $100.0 \%$ \\
\hline Trust & 400 & $100.0 \%$ & 0 & $0.0 \%$ & 400 & $100.0 \%$ \\
\hline
\end{tabular}

Source: Author (2020).

The output of table 2 shows that there were no missing values in all collected data per variable. For the next step, a descriptive statistics analysis was conducted to provide a summary of respondents' backgrounds. Table 3 below presents the background of the respondents based on their responses at the beginning section of questionnaire.

Table 3 - Characteristic of Respondent

\begin{tabular}{|c|c|c|}
\hline Profile & Categories & Percentage (\%) \\
\hline \multirow{6}{*}{ Total flights taken in 1 year } & 1-5 flights & 44 \\
\hline & 6-10 flights & 35.5 \\
\hline & 11-25 flights & 17.5 \\
\hline & 16-20 flights & 2.5 \\
\hline & 46-50 flights & 0.5 \\
\hline & Total & 100 \\
\hline \multirow{6}{*}{ Total flights for business purpose in 1 year } & 1-5 flights & 80 \\
\hline & 6-10 flights & 8 \\
\hline & 11-15 flights & 9.5 \\
\hline & 16-20 flights & 2 \\
\hline & $21-25$ flights & 0.5 \\
\hline & Total & 100 \\
\hline \multirow{6}{*}{ Total flights for leisure purpose in 1 year } & 1-5 flights & 86 \\
\hline & 6-10 flights & 8 \\
\hline & 11-15 flights & 5 \\
\hline & 16-20 flights & 0.5 \\
\hline & 21-25 flights & 0.5 \\
\hline & Total & 100 \\
\hline \multirow{5}{*}{ Favourite way to book flight tickets } & Via airline website & 17 \\
\hline & Via third party website & 55 \\
\hline & Via travel agency website & 23 \\
\hline & Via social media & 5 \\
\hline & Total & 100 \\
\hline \multirow{3}{*}{ Join airline membership program } & No & 97.5 \\
\hline & Yes & 2.5 \\
\hline & Total & 100 \\
\hline \multirow{6}{*}{ Technology adoption level (1-7) } & 3 & 2 \\
\hline & 4 & 39.5 \\
\hline & 5 & 41.5 \\
\hline & 6 & 14.5 \\
\hline & 7 & 2.5 \\
\hline & Total & 100 \\
\hline
\end{tabular}

Source: Author (2020).

Table 3 above explains that $79.5 \%$ of millennial respondents had taken 1-10 flights in the last year. At least $80 \%$ of respondents took 1-5 flights for business purpose, as well as for leisure purpose. The favorite way to book flight tickets was via third party websites (55\% of respondents) such as Traveloka.com, Booking.com and Misteraladin.com, while the second most popular way was via travel agency websites (23\% of respondents) such as Chanbrothersflexi.com, Panoramajtb.com and His-travel.co.id. The third most popular way was via airline websites ( $17 \%$ of respondents) such as Lionair.co.id and Airasia.com. The remaining $5 \%$ purchased their tickets from ticket seller's account on social media such as Gold Coast Travel \& Tourism W.L.L with business pages on Facebook. Most respondents never joined airline membership programs $(97.5 \%$ of respondents) and their technology adoption level mostly ranged from 4-6.

Table 4 below presents the result of the Explanatory Factor Analysis (EFA). The EFA used was Barlett's Test of Sphericity and the Kaiser-Meyer-Olkin (KMO) method (Miller, 2017). This resulted in a KMO value of 0.828 and all the factor loadings were above 0.5 , confirming that the construct was valid. 
Table 4 - Factor Analysis

\begin{tabular}{|c|c|c|c|c|c|c|}
\hline \multirow{2}{*}{$\begin{array}{l}\text { KMO } \\
0.828\end{array}$} & \multicolumn{6}{|c|}{ Component } \\
\hline & 1 & 2 & 3 & 4 & 5 & 6 \\
\hline HF1 & 0.82 & & & & & \\
\hline HF3 & 0.81 & & & & & \\
\hline HF2 & 0.81 & & & & & \\
\hline HF4 & 0.80 & & & & & \\
\hline HF5 & 0.73 & & & & & \\
\hline EL2 & & 0.86 & & & & \\
\hline EL3 & & 0.85 & & & & \\
\hline EL1 & & 0.82 & & & & \\
\hline BE1 & & & 0.86 & & & \\
\hline BE3 & & & 0.83 & & & \\
\hline BE2 & & & 0.83 & & & \\
\hline POE3 & & & & 0.84 & & \\
\hline POE1 & & & & 0.82 & & \\
\hline POE2 & & & & 0.81 & & \\
\hline UF2 & & & & & 0.86 & \\
\hline UF1 & & & & & 0.82 & \\
\hline UF3 & & & & & 0.81 & \\
\hline $\mathrm{T} 2$ & & & & & & 0.86 \\
\hline $\mathrm{T} 1$ & & & & & & 0.81 \\
\hline
\end{tabular}

Extraction Method: Principal Component Analysis. / Rotation Method: Varimax with Kaiser Normalization. Rotation converged in 5 iterations.

Source: Author (2020).

Confirmatory Factor Analysis (CFA) was performed next to help with the assessment of convergent validity, discriminant validity and reliability of the construct. Figure 2 below presents the last version of confirmatory factor analysis diagram.

Figure 2 - Confirmatory Factor Analysis

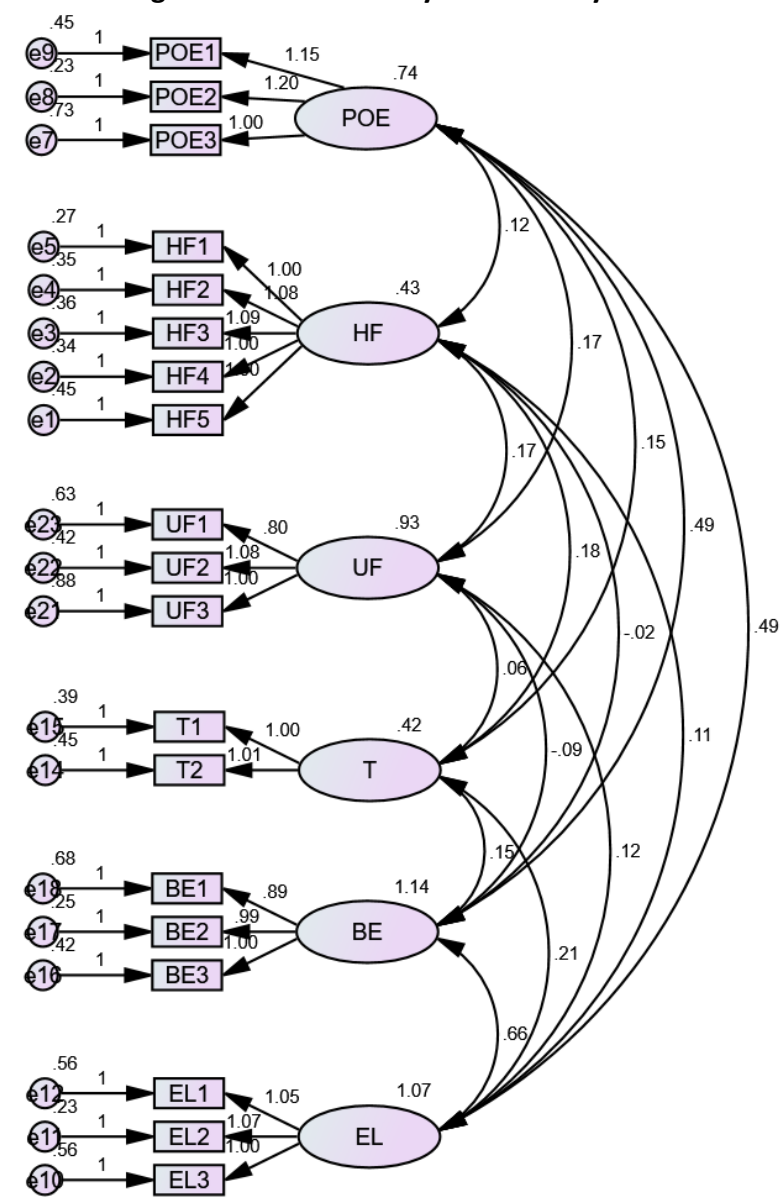

Source: Author (2020). 
Some items were deleted as a consequence of the EFA and CFA analysis because the factor loading did not meet the minimum criteria of 0.5 . The deleted items were POE_4, UF_4, T_3, T_4 and BE_4. Table 5 below presents a summary of composite reliability, average of variance extracted, Cronbach's alpha, maximum shared variance and maximum reliability for validity and reliability measurement.

Table 5 - Validity and Reliability Statistic

\begin{tabular}{|l|c|c|c|c|c|}
\hline \multicolumn{1}{|c|}{ Construct } & CR & AVE & $\boldsymbol{\alpha}$ & MSV & MaxR(H) \\
\hline Brand Equity & 0.878 & 0.707 & 0.870 & 0.353 & 0.895 \\
\hline Hedonic Features & 0.867 & 0.567 & 0.839 & 0.187 & 0.869 \\
\hline Positive Online Experience & 0.857 & 0.669 & 0.852 & 0.305 & 0.882 \\
\hline Utilitarian Features & 0.800 & 0.573 & 0.794 & 0.076 & 0.822 \\
\hline Trust & 0.864 & 0.506 & 0.801 & 0.187 & 0.702 \\
\hline E-Loyalty & 0.886 & 0.723 & 0.813 & 0.353 & 0.902 \\
\hline
\end{tabular}

Source: Author (2020).

The Average Variance Extracted (AVE) was above 0.5, which indicates that convergent validity was not an issue. Reliability was confirmed using Cronbach's alpha and the composite reliability (CR) of each construct exceeded 0.7 . Therefore, the measurement model and data were reliable (Hair et.al, 2010). Table 6 below presents the squared root of AVE and squared correlation between each construct for a discriminant validity assessment.

Table 6 - Discriminant Validity

\begin{tabular}{|l|c|c|c|c|c|c|}
\hline \multicolumn{1}{|c|}{ Construct } & $\mathbf{1}$ & $\mathbf{2}$ & $\mathbf{3}$ & $\mathbf{4}$ & $\mathbf{5}$ & $\mathbf{6}$ \\
\hline Brand Equity & $\mathbf{0 . 8 4 1}$ & & & & & \\
\hline Hedonic Features & 0.029 & $\mathbf{0 . 7 5 3}$ & & & & \\
\hline Positive Online Experience & 0.536 & 0.223 & $\mathbf{0 . 8 1 8}$ & & & \\
\hline Utilitarian Features & 0.088 & 0.276 & 0.209 & $\mathbf{0 . 7 5 7}$ & & \\
\hline Trust & 0.190 & 0.433 & 0.248 & 0.112 & $\mathbf{0 . 6 3 7}$ & \\
\hline E-Loyalty & 0.594 & 0.160 & 0.552 & 0.124 & 0.279 & $\mathbf{0 . 8 5 0}$ \\
\hline
\end{tabular}

Discriminant validity was identified by comparing squared root of AVE to squared correlation between each construct (Miller, 2017). The result shows that all the squared roots of AVE were higher than the squared correlations between pairs of construct, indicating that discriminant validity was achieved. Table 7 below presents normality test result of final data.

Table 7 - Normality Test Result

\begin{tabular}{|c|c|c|c|c|c|c|c|}
\hline \multicolumn{8}{|c|}{ One-Sample Kolmogorov-Smirnov Test } \\
\hline & & POE & $\mathrm{HF}$ & UF & $\mathrm{T}$ & $\mathrm{BE}$ & EL \\
\hline \multicolumn{2}{|c|}{$\mathrm{N}$} & 400 & 400 & 400 & 400 & 400 & 400 \\
\hline \multirow{2}{*}{$\begin{array}{l}\text { Normal } \\
\text { Parameters }{ }^{\mathrm{a}, \mathrm{b}}\end{array}$} & Mean & 4.5867 & 4.5355 & 4.5525 & 4.5888 & 4.6483 & 4.6725 \\
\hline & Std. Deviation & 1.00250 & 0.76367 & 1.04001 & 0.89359 & 0.98255 & 1.01491 \\
\hline \multirow{3}{*}{$\begin{array}{l}\text { Most Extreme } \\
\text { Differences }\end{array}$} & Absolute & 0.163 & 0.125 & 0.159 & 0.165 & 0.110 & 0.108 \\
\hline & Positive & 0.079 & 0.062 & 0.082 & 0.113 & 0.084 & 0.095 \\
\hline & Negative & -0.163 & -0.125 & -0.159 & -0.165 & -0.110 & -0.108 \\
\hline \multicolumn{2}{|l|}{ Test Statistic } & 0.163 & 0.125 & 0.159 & .0165 & 0.110 & 0.108 \\
\hline \multicolumn{2}{|c|}{ Asymp. Sig. (2-tailed) } & $0.000^{c}$ & $0.000^{c}$ & $0.000^{c}$ & $0.000^{c}$ & $0.000^{c}$ & $0.000^{c}$ \\
\hline
\end{tabular}

a. Test distribution is Normal. / b. Calculated from data. / c. Lilliefors Significance Correction.

Source: Author (2020).

A Normality Test was performed using the One-Sample Kolmogorov-Smirnov Test. The table above shows that none of the test statistics of any variable were significant (the value > $0.05)$, which indicated that the data was normally distributed
(Miller, 2017). In addition, a Q-Q Plot Normality Test was performed to visually show that the data was normal. The figure 3 below shows the plot. 
Figure 3-Q-Q Plot Normality Test

Normal P.P Plot of Regression Standardized Residual

Dependent Variable: EL

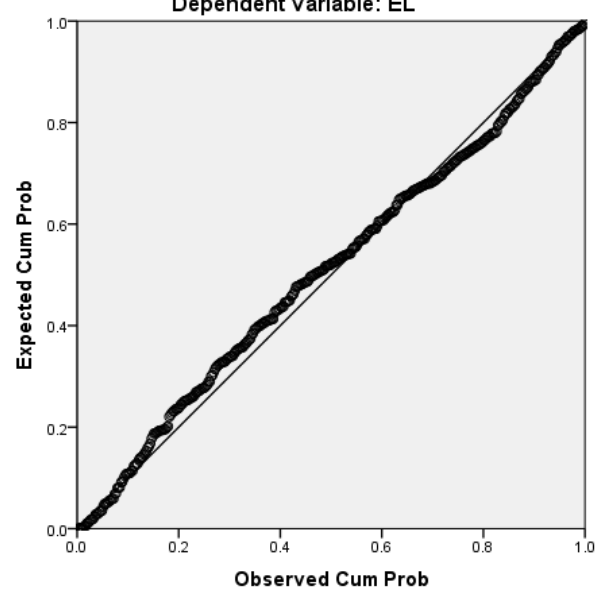

Source: Author (2020)

Figure 3 above shows that the data was normally distributed because the points lie close to the straight diagonal line. This is also an indication that there were no extreme outliers in the data (Miller, 2017). A multicollinearity test was performed by finding the tolerance and Variance Inflation Factor (VIF) for each exogenous latent variable.

Table 8 - Multicollinearity Test Result

\begin{tabular}{|l|c|c|}
\hline \multicolumn{1}{|c|}{ Construct } & Tolerance & VIF \\
\hline Positive Online Experience & 0.776 & 1.289 \\
\hline Hedonic Features & 0.851 & 1.176 \\
\hline Utilitarian Features & 0.851 & 1.175 \\
\hline Trust & 0.808 & 1.238 \\
\hline Brand Equity & 0.828 & 1.208 \\
\hline Dependent Variable: EL
\end{tabular}

Source: Author (2020).

The Variance Inflation Factor (VIF) for each exogenous latent variable was less than 10 which indicated that there were no multicollinearity problem in the data. Table 9 below presents
Goodness-of-fit measurements to see how fit the models were to answer research aims, perquisite to hypothesis testing.

Table 9 - Model Fit Evaluation

\begin{tabular}{|c|c|c|c|}
\hline Model Fit Index & Recommended Value & Analysis Result & Decision \\
\hline CMIN/DF & 4.00 or below & 1.11 & Passed \\
\hline NFI & 0.90 or above & 0.90 & Passed \\
\hline RMSEA & 0.07 or below & 0.05 & Passed \\
\hline CFI & 0.90 or above & 0.96 & Passed \\
\hline GFI & 0.90 or above & 0.95 & Passed \\
\hline TLI & 0.90 or above & 0.94 & Passed \\
\hline IFI & 0.90 or above & 0.90 & Passed \\
\hline
\end{tabular}

Good model measurement results were found such as $X^{2} / d f$ equal to 1.11, an NFI of 0.90, a RMSEA of 0.05 , a CFI of 0.96 , a GFI of 0.95, a TLI of 0.94 and an IFI of 0.90 . The model was fit according to the recommended values of Hair et al (2010) as above. After the model measurements were found to be good, path analysis was performed to see if the hypotheses were accepted or rejected. Figure 4 below presents the analysis result of path diagram. 


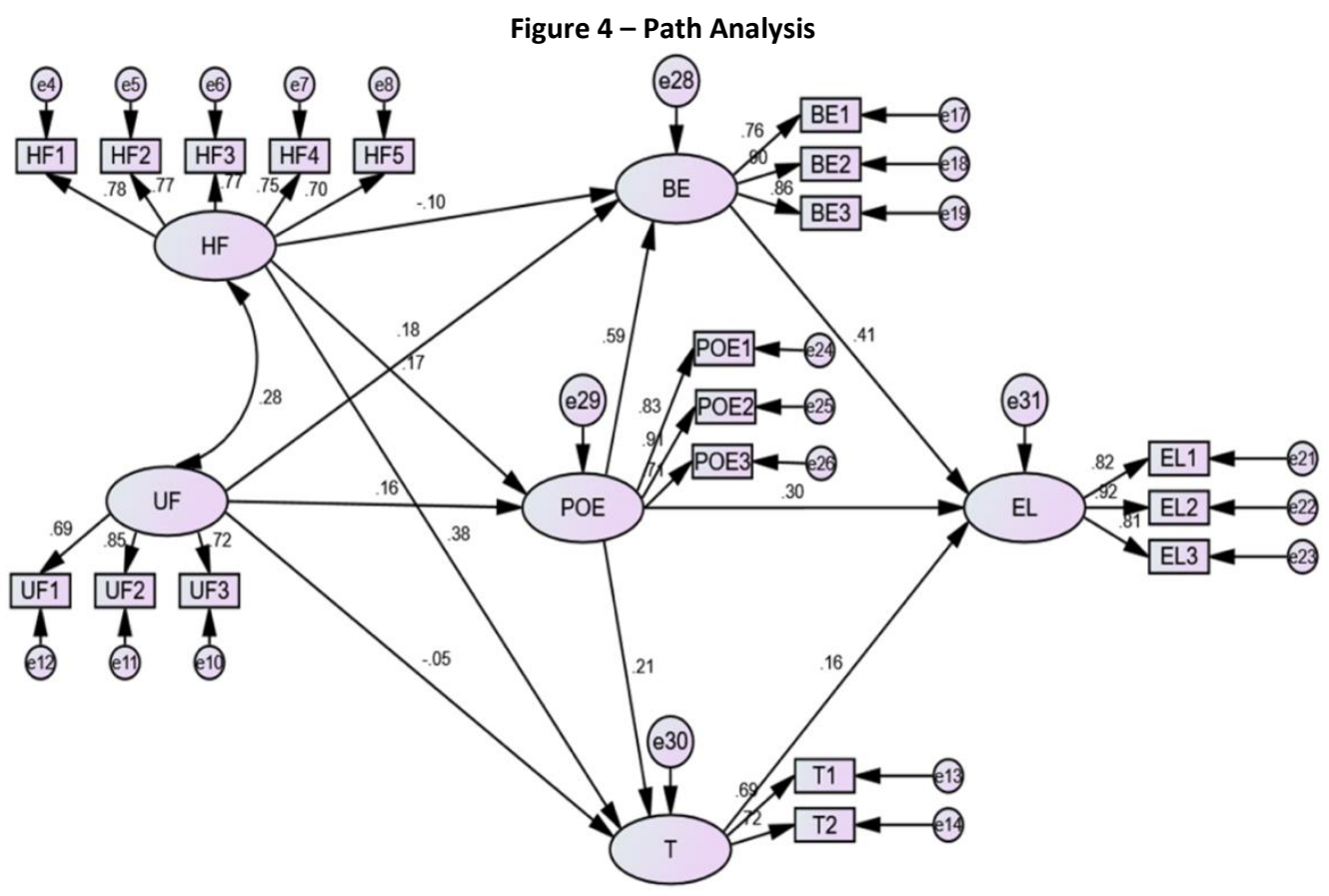

Source: Author (2020).

The path diagram above shows standardized estimates for each path. In order to accept or reject a hypothesis, one must look at the critical ratio (CR) and $P$ value. A critical ratio (CR) more than 1.96 and a $P$ value less than 0.05 indicate that the hypothesis is accepted which means there is a significant effect of one variable on the other. Table 10 below presents a path analysis summary. Each hypothesis is explained further in section 5 (Discussions).

Table 10 - Path Analysis Summary

\begin{tabular}{|c|c|c|c|c|c|c|c|}
\hline \multicolumn{3}{|c|}{ Hypothesis } & Estimate & S.E. & C.R. & $\mathrm{P}$ & Hypothesis Supported \\
\hline $\mathrm{POE}$ & <-- & UF & 0.162 & 0.111 & 2.048 & 0.011 & Yes \\
\hline POE & $<--$ & $\mathrm{HF}$ & 0.173 & 0.125 & 2.023 & 0.023 & Yes \\
\hline $\mathrm{BE}$ & $<--$ & UF & 0.179 & 0.098 & 2.242 & 0.008 & Yes \\
\hline $\mathrm{T}$ & $<--$ & UF & -0.049 & 0.078 & -0.405 & 0.543 & No \\
\hline $\mathrm{BE}$ & $<--$ & $\mathrm{HF}$ & -0.103 & 0.109 & -1.454 & 0.092 & No \\
\hline$T$ & $<<--$ & $\mathrm{HF}$ & 0.385 & 0.1 & 4.294 & *** & Yes \\
\hline $\mathrm{BE}$ & $<--$ & POE & 0.594 & 0.083 & 6.543 & $* * *$ & Yes \\
\hline$T$ & $<--$ & POE & 0.212 & 0.059 & 2.343 & 0.006 & Yes \\
\hline $\mathrm{EL}$ & <--- & $\mathrm{BE}$ & 0.408 & 0.094 & 5.432 & *** & Yes \\
\hline EL & $<<--$ & $\mathrm{POE}$ & 0.295 & 0.093 & 3.543 & $* * *$ & Yes \\
\hline EL & <--- & $T$ & 0.157 & 0.137 & 2.249 & 0.007 & Yes \\
\hline
\end{tabular}

\section{Discussions}

\subsection{Interrelationship between Hedonic Features and Flow (Positive Online Experience)}

Hedonic features of flight booking websites such as having a creative and unique website layout, beautiful background, music, the type of font and the use of pleasing video that affects emotional aspect of user when visiting the website significantly and positively contributes to the online experience of millennial in Southeast Asian countries ( $\mathrm{H} 1, \mathrm{p}<0.05$, estimate $=0.023$ ). Therefore it is essential to pay attention to these website features in order to turn website visitors into loyal customers. This result of this study is in line with previous research as features like virtual tours and appealing website design can make consumers like a website more when searching for hotels (Bilgihan, 2016). This research output is also in line with Mahnke et al (2015) which states that greater hedonic features of website will lead to better experience. Creating positive online experiences can be achieved by satisfying users' feelings, fantasies and pleasure senses. With the sense of total enjoyment and concentration, users spend more time on the website and finally search for information about the best product and price in enjoyable moment. It can trigger them to revisit the website in the future. Online positive experiences can also come from format such as type and size of fonts, layout, sound effects, animation and color combination that can increase the overall website visual attractiveness. 


\subsection{Interrelationship between Utilitarian Features and Flow}

Utilitarian features of flight booking websites are found to be a significant factor to positive online experience $(\mathrm{H} 2, \mathrm{p}<0.05$, estimate $=0.162$ ). Websites should have appropriate utilitarian features as such price comparison and filtering features, reviews, searching by name or location and other information that can make users enjoy using the website for flight ticket reservation. These features do not only make website more competitive but also make customers loyal and wanting to revisit it again for their next purchase. Detail filters and ease of use are good for making users highly concentrated in their search for flight. The higher quality of utilitarian features will lead to a more positive online experience of the users. Previous research from Chen, Chang, and Chen (2017) and Mahnke et al (2015) revealed that utilitarian features play a major role in stimulating e-commerce website users to repurchase and revisit the website. Information and system quality of a website are determinants to hedonic and utilitarian values that can evoke lasting participating behavior.

\subsection{Interrelationship between Hedonic Features and Brand Equity}

While previous literature found that hedonic features increase positive online experiences, this study did not prove that they increase the brand equity of the website $(H 3, p=0.092$, estimate $=-0.103)$. This research output is not in line with previous research such as Bilgihan (2016) and Kang \& Tasci (2017) who said that hedonic features can increase the brand equity of a website. This is still inconclusive and further investigation is neded to reconfirm this result. The temporary assumption for this phenomenon is that Southeast Asian millennial users are not attracted to the brand when they use a website, which is in line with Olga et al (2018) who confirmed that Millennials are less loyal to brands compared to the previous generation. Companies must create more personalization and branding features on their website such as slogans, brand ambassadors, brand voices and tone to increase brand association among its users in order to increase their brand equity.

\subsection{Interrelationship between Utilitarian Features and Brand Equity}

The positive contribution of utilitarian features to the brand equity of a website is proven. Southeast Asian Millennials highly appreciate booking websites that can help them find the best flight easily. When they can find such a website, they will pay attention to the brand and try to remember it. Users will have a positive perception of a specific brand when the website has good utilitarian features $(H 4, p<0.05$, estimate $=0.179)$. This finding is supported by previous research such as Foroudi et al (2019) who argued that utilitarian consumer behavior has a strong direct significant influence towards brand equity. Price is still major concern for Southeast Asian Millennials when booking flights, therefore they will remember the brand of websites that can help them in finding the cheapest ticket easily so that they can revisit it and recommend it to their relatives.

\subsection{Interrelationship between Flow and Brand Equity}

When Southeast Asian Millennials experiences flow or positive online experience, they will be aware of the website brand ( $\mathrm{H} 5$, $p<0.05$, estimate $=0.594$ ). Bilgihan (2016) and Fu, Kang \& Tasci (2017) supported this finding by confirming that in virtual contexts, positive online experience and brand equity are strongly connected. Flow immerses users in the virtual context of the website, a formulation that increases brand equity and positively influences users' memory toward the brand. Customers' attitudes toward a brand can be stimulated by increasing the perceived quality of online experiences as this can increase users' awareness towards a particular brand and therefore bring benefits to the company (Jamshidi et al, 2018).

\subsection{Interrelationship between Flow and Trust}

As mentioned above, flow or positive online experience can stimulate positive customer attitude towards a particular brand. Apparently, the effect of flow on trust towards a website is also statistically significant $(H 6, p<0.05$, estimate $=0.212)$. This finding is in line with previous research by Jamshidi et al (2018) who found that trust has a strong relationship with flow. Once a customer gains flow, they will trust the website more than before. Creating positive online experience is a good trust building strategy. Trust is important because Millennials are exposed to many risks in online transaction everyday. Customers want a guarantee that they do have a booked seat when they arrive at the airport. If this does not happen, users will switch to other websites because of the trauma. Positive experience in using the website can produce positive thinking because it can give them sense of the company's professionalism (Bilgihan, 2016).

\subsection{Interrelationship between Flow and E-Loyalty}

Flow or positive online experience is also significantly proven to be a positive contributor to e-loyalty $(H 7, p<0.05$, estimate $=$ $0.295)$. When users gain flow, they are theoretically motivated to revisit the website because they want to experience it again and engage with it. Previously, Bilgihan (2016) and Su et al (2016) confirmed that positive online experience is a significant factor towards e-loyalty and it is in line with this research. It is important to keep users achieving a state of flow during the online booking process so that they will be loyal to the website. When users become loyal to a website, they will not be influenced to switch to another website and they tend to recommend the site to their relatives bringing long-term benefits to the company.

\subsection{Interrelationship between Brand Equity and E-Loyalt}

Many researchers have confirmed the strong correlation between brand equity and customer loyalty. This research again confirms that brand equity can increase loyalty in an online environment $(H 8, p<0.05$, estimate $=0.408)$. The significant 
and positive impact provided by brand equity shows that it is direct factor for e-loyalty. Users feel safe when they use the website of a famous company and therefore they will use it again when they need to make a purchase in the future. Anything associated with positive news and reviews from media will lead to strong loyalty because users heavily rely on the website for their trip. When a company fails to keep its promise, consumers will have problem when they arrive at the airport for their flight. This does not only hurt them financially but also psychologically. In the consumer mindset, famous brands are usually associated with a company's reputation and service quality therefore marketers are expected to manage their branding on website in order to increase e-loyalty of the users (Quan et al, 2020).

\subsection{Interrelationship between Trust and E-Loyalty}

It is statistically found that trust positively affects e-loyalty (H9, $p<0.05$, estimate $=0.157)$. This finding is in line with previous research (Wang, Wang, \& Liu, 2016) which stated that trust should be highlighted as contributor to e-loyalty in an e-service environment. Online reviews on websites should be a major concern for companies because they heavily affect users' trust towards the website. Guarantee policies must be considered by company to build up trust in consumers' minds along with information clarity and the identity of company. Bilgihan (2016) said that in order to convince consumers, certificates of excellence should be publicly shown. Some research institutions such as Nielsen, Frontier and Deloitte often conduct surveys to give awards to the most popular brand in a specific country, ; such an award can be used to build up trust so that the company can have more loyal customers.

\subsection{Interrelationship between Hedonic Features and Trust}

The results revealed that the hedonic features of flight booking website can increase the trust of Millennials towards a website in Southeast Asia countries ( $\mathrm{H} 10, \mathrm{p}<0.05$, estimate $=0.385)$. If companies can manipulate consumers' emotions by adding more hedonic features to its website, then a company can utilize the website to build up trust. Appealing and beautiful user interface design is perceived by Southeast Asian millennial as a reflection of the professionalism and hard work of a reputable company therefore making them perceive the company as trustworthy (Pengnate \& Sarathy 2017). Bilgihan (2016) previously revealed that companies must make improvements such as presenting entertaining, exciting and delightful features on their booking websites to increase the trust of its users. Millennials love creativity and therefore a beautifully designed website is perceived as point of differentiation that reflects a company's creativeness, making millennial consumers more interested to the company.

\subsection{Interrelationship between Utilitarian Features and Trust}

Unlike hedonic features, utilitarian features do not significantly affect the trust of gen $Y$ towards a website $(H 11, p=0.543$, estimate $=-0.049$ ). Highly innovative utilitarian features on a website do not automatically make Southeast Asian Millennials trust the website. Previously, Kamal et al (2018) said that utilitarian features are an important determinant for developing online trust. Experience creates alertness among millenials who have been exposed to risk in daily online activity. It indicates that there are other factors affecting the trust of Millennials towards a website that are not included in this research. Therefore further examination is expected to determine these factors.

This study adopts the research model of a highly reputable researcher (Bilgihan, 2016) who previously used the model to study e-loyalty of American Millennials toward hotel booking websites. This study has brought a new academic contribution as it successfully reconfirms that the e-loyalty model works for Southeast Asian Millennials in an online booking context. The successful application towards flight booking websites opens possibility that Bilgihan's model does not only work for hotel booking website but also other products in the tourism sector. However, despite of all positive and significant contributions, the effect of utilitarian features towards trust and hedonic features towards brand equity are found to be insignificant, which indicates that Bilgihan's model does not perfectly fit when it is applied to other products or regions.

Airline and travel companies can use this study as baseline for their website strategy. They should add and improve their utilitarian and hedonic features on their websites to increase brand equity, flow and trust that can make their customers more loyal their website, resulting in revisits. Positive online experience (flow) is a non-negotiable factor and must be taken into account when a company wants to utilize its website to build up e-loyalty of its users. Companies are suggested to improve their utilitarian features (features that are related to logical thinking) such as innovative filters and to present valuable information about each flight and the airline company. Ease of use, price comparison features, updated information, maps and responsive customer service chat boxes can also increase positive online experience and the brand equity of gen $Y$ toward the website. Another important set of features is hedonic features (features related to emotional feeling) such as innovative layout design, music, images and the website's color combination that can increase trust and the positive online experience of Southeast Asian Millennials.

Like other studies, this study has limitations that should be addressed. This study is replication study of novel research and therefore provides no new variables in the research model. This study does not also employ demographic control variable therefore it is unable to see how demographic factors such as the gender, age, education, occupation and culture of respondents affect the results of the study. Future researchers are expected to employ demographic factor as control variables to gain more detailed information about the effectiveness of model and to make experimental research that enriches the literature. Adding new variables is also suggested to develop the framework and produce new theoretical perspectives. This 
application can also be expanded to other generations such as generation $\mathrm{X}$ and generation $\mathrm{Z}$ to see if there is possibility for companies to build up e-loyalty among them.

\section{Conclusion}

This study has successfully retested the E-loyalty model from Bilgihan (2016) to understand how Millennials become loyal to flight booking websites in Southeast Asia. Good utilitarian features of website can significantly increase brand equity and the positive online experience (flow) of website users while good hedonic features of website can significantly increase positive online experiences and the trust of website users. Brand equity, positive online experiences and trust have direct and significant effects on e-loyalty. When the brand equity of website, positive online experience and trust of website users are higher, the e-loyalty of millennial customers toward the website is higher.

The effect of utilitarian features on trust and hedonic features on brand equity are found to be insignificant, which indicates that Bilgihan's model does not perfectly fit when applied to other products or regions. Nevertheless, as the other hypotheses are accepted, it can be concluded that the model works well enough for Southeast Asian Millennials and flight booking websites.

\section{Declaration of Conflicting Interests}

The author declares no potential conflicts of interest with respect to the research, authorship, and/or publication of this article.

\section{Funding}

The author received no financial support for the research, authorship, and/or publication of this article.

\section{Acknowledgement}

I would like to express my gratitude to Jacob Bills for extended discussions and valuable suggestions which have contributed greatly to the improvement of my paper.

\section{References}

Asian Development Bank. (2017). Asian Development Outlook 2017, p. 69. Manila: Asian Development Bank.

Bilgihan, A. (2016). Gen Y customer loyalty in online shopping: An integrated model of trust, user experience and branding. Computers in Human Behaviour, 61, 103-113.

Cavagnaro, E., Staffieri, S., \& Postma, A. (2018). Understanding millennials' tourism experience: values and meaning to travel as a key for identifying target clusters for youth (sustainable) tourism. Journal of Tourism Futures, 4(1), 31-42.

Chang, H. H., \& Chen, S. W. (2009). Consumer perception of interface quality, security, and loyalty in electronic commerce. Information \& Management, 46(7), 411-417.

Chen, W.-K., Chang, D.-S., \& Chen, C.-C. (2017). The Role of Utilitarian and Hedonic Values on Users' Continued Usage and Purchase Intention in a Social Commerce Environment. Journal of Economics and Management, 13(2), 193-220.

EMAMR. (2009). The 2009 Entertainment, Media \& Advertising Market Research Handbook. Atlanta: Richard K. Miller \& Associates.

Foroudi, P., Yu, Q., Gupta, S., \& Foroudi, M. M. (2019). Enhancing university brand image and reputation through customer value co- creation behaviour. Technological Forecasting and Social Change, 138, 218-227.

Fu, X., Kang, J., \& Tasci, A. (2017). Self-congruity and flow as antecedents of attitude and loyalty towards a theme park brand. Journal of Travel \& Tourism Marketing, 34(9), 1261-1273.

Google, \& MediaCT, I. (2012). The 2012 Traveller. from http://www.biggestleaf.com/wp-content/uploads/2012_the-2012traveler.pdf

Hair, J. F., Black, W. C., Babin, B. J., Anderson, R. E., \& Tatham, R. L. (2010). Multivariate data analysis (Vol. 5): Prentice hall Upper Saddle River, NJ.

Hamid, A. B. A., Mousavi, S. B., \& Partovi, B. (2019). Managing E-Crm Towards Customer Satisfaction and Quality Relationship. Singapore: Partridge Publishing Singapore.

Huang, M. H. (2003). Designing website attributes to induce experiential encounters. Computers in Human Behaviour, 19(4), 425-442.

Huang, M. H. (2005). Web performance scale. Information \& Management, 42(6), 841-852.

Jamshidi, D., Keshavarz, Y., Kazemi, F., \& Mohammadian, M. (2018). Mobile banking behavior and flow experience. International Journal of Social Economics, 45(1), 57-81.

Kamal, S. B. M., Abdullah, D., Nor, N. M., Ngelambong, A., \& Bahari, K. A. (2018). Hotel booking websites and their impact on e-satisfaction and e-loyalty: analysis on utilitarian and hedonic features. International Journal of Academic Research in Business and Social Sciences, 8(15), 160-177.

Ketter, E. (2020). Millennial travel: tourism micro-trends of European Generation Y. Journal of Tourism Futures. Advance online publication.

Kim, D. Y., \& Park, S. (2020). Rethinking millennials: how are they shaping the tourism industry?. Asia Pacific Journal of Tourism Research, 25(1), 1-88.

Lin, H.-H., \& Wang, Y.-S. (2006). An examination of the determinants of customer loyalty in mobile commerce contexts. Information \& Management, 43(3), 271-282.

Mandal, P., \& Vong, J. (2016). Development of tourism and the hospitality industry in Southeast Asia. Singapore: Springer Science and Business Media Singapore.

Mang'unyi, E. E., Khabala, O. T., \& Govender, K. K. (2018). Bank customer loyalty and satisfaction: the influence of virtual e-CRM. African Journal of Economic and Management Studies, 9(2), 250-265.

Martín-Consuegra, D., Díaz, E., Gómez, M., \& Molina, A. (2019). Examining consumer luxury brand-related behavior intentions in a social media context: The moderating role of hedonic and utilitarian motivations. Physiology \& Behavior, 200, 104-110.

Miller, R. L. (2017). SPSS for social scientists. New York: Macmillan International Higher Education.

Morgan, R. M., \& Hunt, S. D. (1994). The commitment-trust theory of relationship marketing. The Journal of Marketing, 58(3), 20-38.

Olga, B., David, D. D., Dhameeth, G. S., Adam, S., \& Elliott, S. (2018). The Millennials: Insights to Brand Behavior for Brand Management Strategies. Journal of Management and Strategy, 9(3), 1-17.

Pengnate, S. F., \& Sarathy, R. (2017). An experimental investigation of the influence of website emotional design features on trust in unfamiliar online vendors. Computers in Human Behavior, 67, 49-60.

Quan, N., Chi, N., Nhung, D., Ngan, N., \& Phong, L. (2020). The influence of website brand equity, e-brand experience on e-loyalty: The mediating role of e-satisfaction. Management Science Letters, 10(1), 63-76.

Ritchie, B. W., Chien, P. M., \& Sharifpour, M. (2017). Segmentation by travel related risks: An integrated approach. Journal of Travel \& Tourism Marketing, 34(2), 274-289.

Rose, S., Clark, M., Samouel, P., \& Hair, N. (2012). Online customer experience in e-retailing: an empirical model of antecedents and outcomes. Journal of Retailing, 88(2), 308-322. 
Su, Y. S., Chiang, W. L., Lee, C. T. J., \& Chang, H. C. (2016). The effect of flow experience on player loyalty in mobile game application. Computers in Human Behavior, 63, 240-248.

Veiga, C., Santos, M. C., Águas, P., \& Santos, J. A. C. (2017). Are Millennials transforming global tourism? Challenges for destinations and companies. Worldwide Hospitality and Tourism Themes, 9(6), 603-616.

Wang, W. T., Wang, Y. S., \& Liu, E. R. (2016). The stickiness intention of group buying websites: The integration of the commitment e-trust theory and ecommerce success model. Information \& Management, 53(5), 625-642.

Willems, K., Brengman, M., \& Van Kerrebroeck, H. (2019). The impact of representation media on customer engagement in tourism marketing among Millennials. European Journal of Marketing, 53(9), 1988-2017.

Yoo, B., Donthu, N., \& Lee, S. (2000). An examination of selected marketing mix elements and brand equity. Journal of the Academy of Marketing Science, 28(2), 195-211.

Received: 23.04 .2020

Revisions required: 26.05 .2020

Accepted: 20.07.2020 